For citation: Ekonomika regiona [Economy of Region]. - 2016. — Vol. 12, Issue 4. - pp. 1090-1101

doi 10.17059/2016-4-11

UDC: $338.124 .4: 336.5$

Jel Code: E6, H6, G01

N. B. Alymkulova a), N. U. Atabaev a), J. M. Ganiev ${ }^{\text {b) }}$

a) International Ataturk Alatoo University (Bishkek, Kyrgyzstan; e-mail:nargizalymkulova@gmail.com)

b) Kyrgyzstan-Turkey Manas University (Bishkek, Kyrgyzstan)

\title{
VAR - ANALYSIS OF GLOBAL FINANCIAL ECONOMIC CRISIS IMPACT ON PUBLIC BUDGET AND UNEMPLOYMENT: EVIDENCE FROM THE ECONOMY OF THE KYRGYZ REPUBLIC ${ }^{1}$
}

The Global financial crisis hit the economy of the Kyrgyz Republic by the third wave of its transmission in the early of 2009. The article examines the impact of the Global financial economic crisis on the public budget and unemployment of the Kyrgyz Republic. We analyzed the transmission of the crisis on the public budget firstly and its effect on unemployment level by using the vector autoregression approach (VAR) and quarterly data for 2005-2013 within the framework of IS-LM model for small open economies with floating exchange rate. There is an inverse relationship between the public budget and remittances inflow, liquidity level, volume of deposits, and exchange rate. As a result of the study, the fall in remittances inflows, liquidity level of the banking system, depreciation of the national currency lead to an increase in public revenue. Therefore, the increase in public spending during the crisis period, with the aim of unemployment reduction, may be considered as a crucial policy. The study result allows to policy-makers to exactly know what channels of transmission mechanism transfer the Global crisis on the public budget and its effect on unemployment level of the republic in order to undertake anticrisis macroeconomic policy. The final result of the study indicates that the increase of unemployment level by $1 \%$ requires the increase of public spending by $0.63 \%$.

Keywords: Global financial economic crisis, public budget, transmission channels, Vector Autoregression, unemployment, economy, Kyrgyz Republic, public spending, public revenue, waves of crisis transmission, IS-LM model

\subsection{Introduction}

The sub-prime mortgage crisis in the US was the prelude to a financial and economic crisis the effects of which have been felt all around the world [1]. The international span of the crisis has also been remarkable; essentially, all the industrialized countries have been affected, as well as a large number of developing and emerging economies [2]. The Global crisis transmitted via channels and waves with the speed dependent on the financial-economic integration of the economies to the global processes. The whole picture of the crisis transmission could be presented as its spread by three waves with the credit to the financial and economic sectors channels.

The worldwide measures to deal with the gravest economic crisis since the Great Depression in the 1930s began to show the first signs of recovery in late summer and early autumn 2009 [3]. Countries in the Commonwealth of Independent States (CIS) and South-Eastern Europe (SEE), which were growing faster than those in many other regions in the world before the crisis, were severely hit in 2009,

\footnotetext{
${ }^{1}$ @ Alymkulova N. B., Atabaev N. U., Ganiev J. M. Text. 2016.
}

but also reverted to the growth rapidly in 2010 [4]. Several large Emerging markets embarked on a significant increase of government expenditures/ GDP in 2008, including in Argentina, China, Korea, Mexico and Russia [5]. Furthermore, the expansionary fiscal policy was suggested by the IMF for countries that were faced with the recession [6]. However ability to use such policy is reduced by the fact that most developing countries could not afford to stimulate their economies through fiscal policy because of concerns about policy credibility and debt sustainability $[7,8,9]$ Apparently, one of the concepts put forth by the economist John Maynard Keynes, and advocates that high fiscal deficits are not unusual for developing economies as governments use fiscal deficits to keep aggregate domestic demand at high levels in order to generate growth and employment [10]. As a matter of fact, higher spending raises output and lowers the unemployment rate both in the present and in the future [11]. What should be highlighted is that depressed economy in the light of Global financial crisis is one in which many workers are without employment for an extended period [12]. As forward-looking policy makers, we would desire to see interplay between economic activities which represent us "em- 


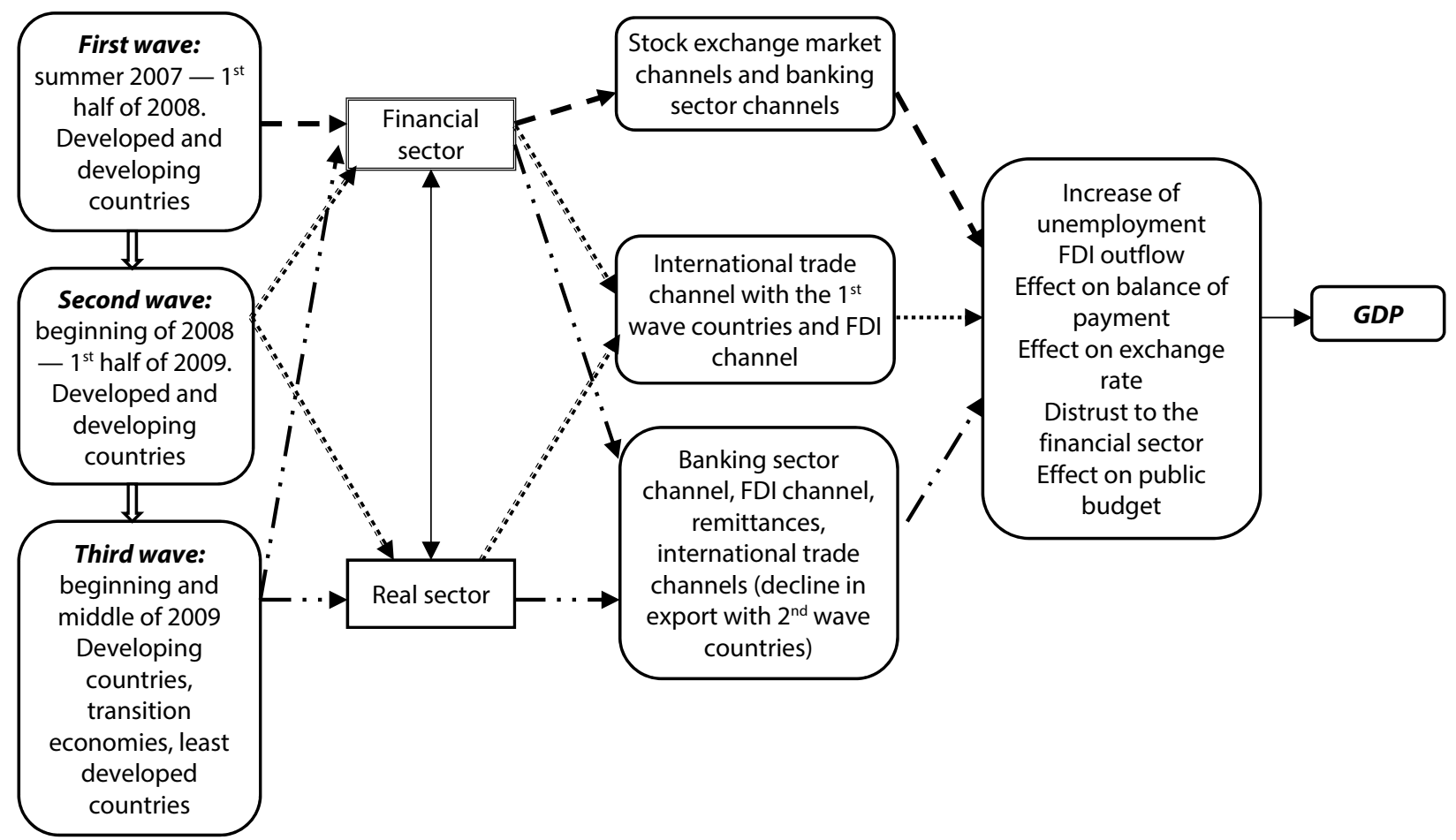

Fig. 1. The global crisis transmission on the world economy

ployment-spending” cycle. Government spending is largely concentrated by government revenue that in turn is determined by economic activity [13].

Nevertheless, IS-LM model suggests that fiscal policy in small open economies with floating exchange rate is more appropriate and effective if not a vital. Moreover, many empirical studies reveal that in developing and emerging countries fiscal policy is a more effective tool for handling with financial crises than monetary policy [14]. An increase in net government spending leads to a rightward shift of the IS curve implying higher output [15]. Hence, after negative shock hits the economy, government spending is not only instrument the fiscal sector can change to boost the economy [16]. On the other hand, the appropriate use of traditional monetary policies led many countries to fall into a liquidity trap where monetary policy can not stimulate investment further.

So the aim of this paper is to investigate the impact of the Global financial crisis on public budget through crisis transmission channels on the small-open economy of the Kyrgyz Republic. Nonetheless, the effect of the expansionary fiscal policy on unemployment level of the republic is studied in the paper.

\subsection{Global financial economic crisis transmission mechanism and public budget}

Theoretical perspectives of the transmission mechanism from the financial crisis to the real economy were studied by Lupu [17]. Basel Committee on
Banking Supervision conducted a research on crisis transmission from financial sector to real sector $^{1}$. Relying on a vast number of research papers examined, we distinguish transmission channels according to the source (place) of the crisis origins. Thereby we mark out the channels of financial and real sectors (Fig. 1). So far financial sector channels include banking sector, FDI flow, remittances flow and exchange rate channels. On the other hand, real sector channels consist of international trade channels, obviously export and import flows. In turn, consequences of the crisis transmission influence on macroeconomic variables such as increase of unemployment level, adverse changes in the balance of payments, effect on the exchange rate, FDI outflow, budget deficit, and distrust to the financial sector primarily to the banking system. As a result, all macroeconomic variable changes impact on GDP (Figure 1). Listed above crisis transmission channels are driven from the point of view of the developing countries that are less integrated into the global financial processes, the impact on which was severe and long lasting. J. Stiglitz [18] argues that countries less integrated into the global financial processes are bear the higher costs of the crisis. V.V. Reddy [19] indicates that the crisis originated in advanced economies, the view of the emerging

\footnotetext{
${ }^{1}$ Basel Committee on Banking Supervision (2011). The transmission channels between the financial and real sectors: a critical survey of the literature. Bank for International Settlements Working paper, 18. Retrieved from: http://www.bis.org/publ/ bcbs_wp18.pdf.
} 


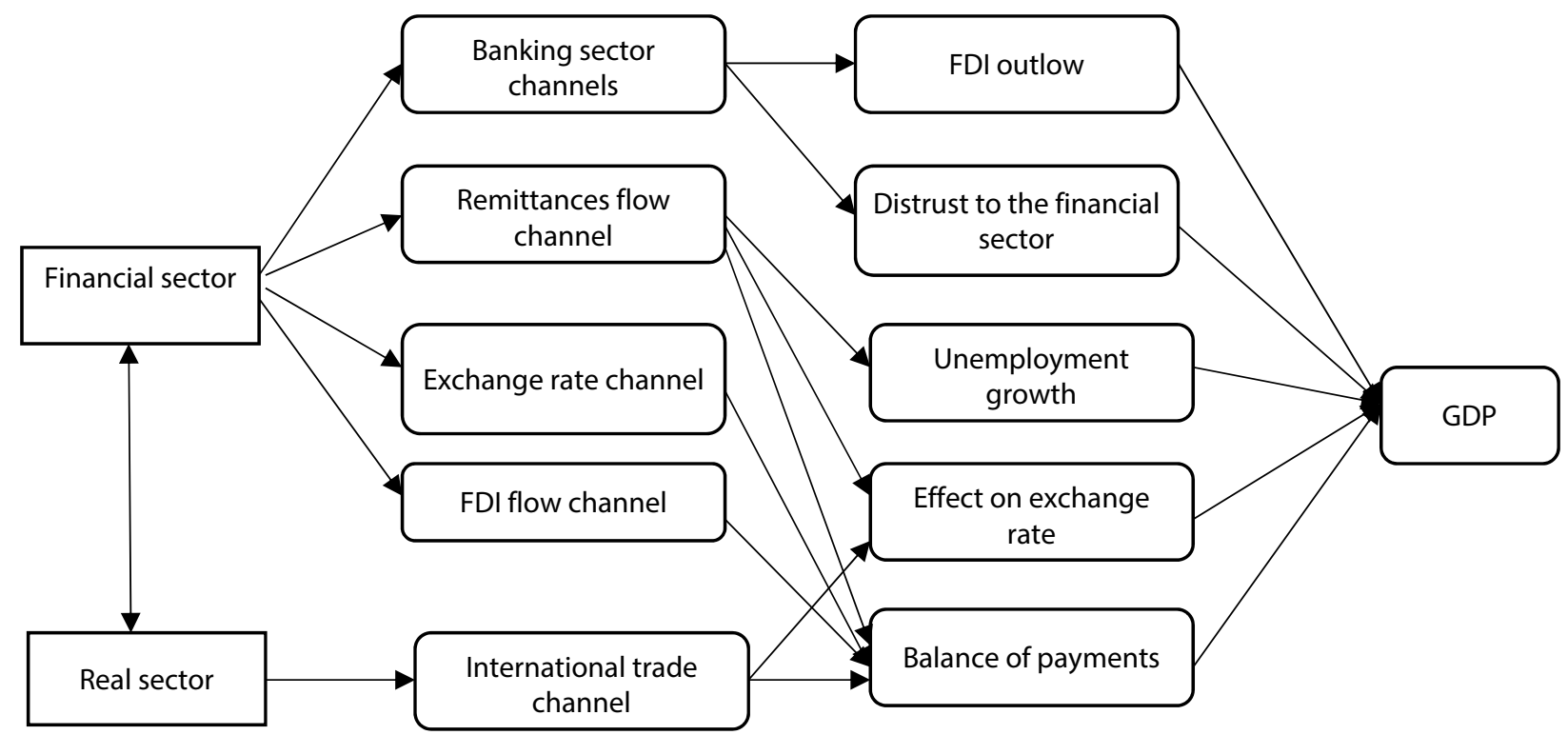

Fig. 2. Global financial crisis transmission on economy of the Kyrgyz Republic

markets, which had to bear its brunt, needs to be articulated. The low-income developing countries were less exposed to the first phase of the crisis, by virtue of their more limited financial integration, and thereby by limited exposure to the pressure induced by capital outflows [5].

Since there is a low level of Kyrgyz Republic inclusion to the global financial and economic processes, it is obvious that channels of transmission would be divergent. The crisis transmission channels and their impact on macroeconomic variables are shown in Figure 2.

In order to see the impact of the Global financial crisis the transmission mechanism should be studied solely. The key transmission channels for the Kyrgyz Republic are mostly financial sector channels comparatively banking sector, remittances inflow, exchange rate, FDI channels, notwithstanding the real sector channels including international trade. All transmission channels caused the macroeconomic variables of a country essentially FDI outflow, unemployment rate, the effect on the exchange rate and balance of payment, as well as public budget, and as aftermaths the GDP.

The public budget of the Kyrgyz Republic has been largely in imbalance, except for the periods of 2005, 2007 and 2008. It is worth noting that in the context of the Global financial crisis that a marked surplus of the public budget and later on since 2009 it has demonstrated only the adverse budget balance indicators as a result of third wave crisis transmission in the early of 2009 , whilst it has reached $-1.45 \%$ to GDP. This is in line with the substantial increase of unemployment rate long since of the late of 2008 and early 2009 , when unemployment level increased by $0.2 \%$ according to the official statistics (Fig. 3).

Obviously, the significant effect on a public budget in the light of the Global financial crisis

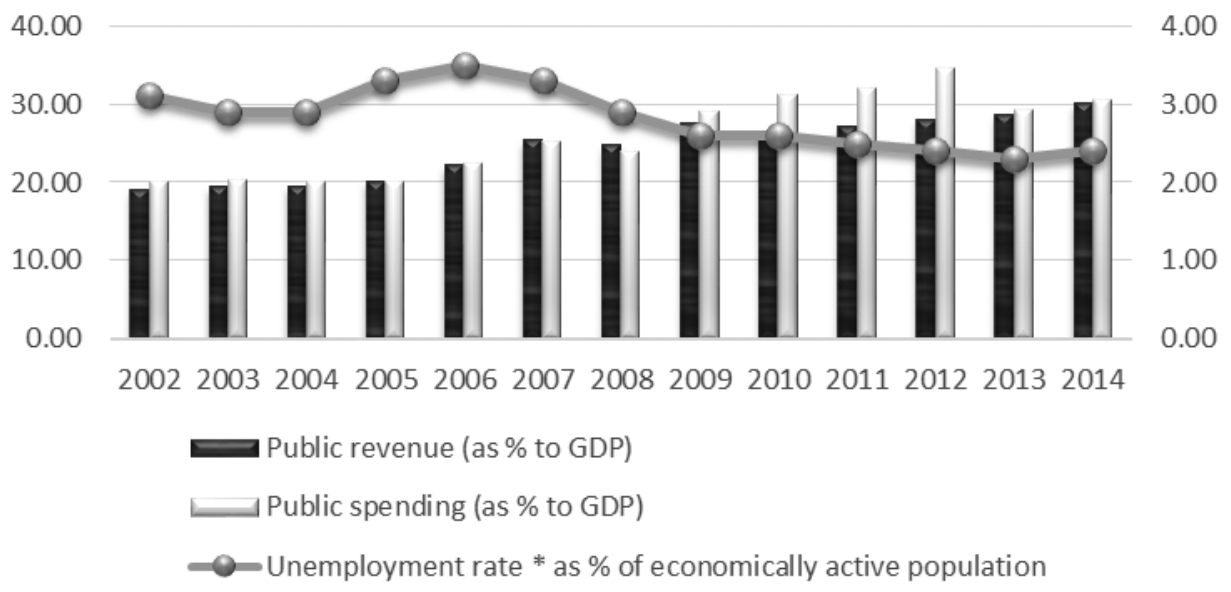

Fig. 3. Public budget and unemployment rate in the Kyrgyz Republic 
needs to be assessed empirically. However, until a short time ago, from a theoretical and empirical standpoint, fiscal policy was given a secondary role, fiscal requirements were taken as irrelevant in research articles [20]. There is a reason also to consider labour market policies in general and active labour market policies in particular, since public finances are very sensitive to the employment rate [21].

\subsection{Hypotheses development}

During the Global financial economic crisis, in small open economies with floating exchange rate, including economy of the Kyrgyz Republic, national currency tend to depreciate, which in turn would cut import volume and remittances inflow, but in contrast this leads to decrease in deficit of trade balance, which is positive effect of the Global crisis. Therefore, monetary authorities would implement foreign exchange interventions to appreciate the national currency. In order to achieve macroeconomic stability within the Mundell-Fleming IS-LM model, the key point is given to the government. Thus, an expansionary monetary policy now would raise economic activity because tendencies towards an outflow of capital and lower interest rates weaken the exchange rate, which in turn encourages net exports [22]. Consecutively, that will lead to the increase of government spending (government purchases). Similarly, in the model, an economy achieves stability when it sustained a targeted unemployment rate. Coenen et al. [23] emphasized that fiscal policy has a strong impact on the economy when monetary policy does not respond.

There are few works examined impact of public spending on unemployment. Likewise, Holden et al estimated the effect of government purchases on unemployment in 20 OECD countries for the period 1980-2007. Monacelli et al. [24], Auerbach and Gorodnichenko [25] and Ramey [26] confirmed in their studies that an increase in government purchases leads to decrease unemployment. In Kyrgyzstan before has not been done any study on Global financial economic crisis impact on the public budget and unemployment, as well as interplay between public spending and unemployment.

Based on the literature we have designed the following hypotheses:

Hypothesis 1: There is significant impact of Global financial economic crisis through transmission channels on public budget and unemployment;

Hypothesis 2: There is the significant inverse impact of public spending on unemployment.

\section{Methods}

\subsection{Empirical model}

Since the critique of Sims (1980) in the early eighties of the last century, multivariate data analysis in the context of vector autoregressive models (henceforth: VAR) has evolved as standard instruments in econometrics [27].

VAR model (Vector autoregressive model) is used to for multivariate time series. The model is structured in the way that each variable is a linear function of past lags of itself and past lags of the other variables. One important characteristic of VAR is its stability. Therefore, it generates stationary time series with time-invariant means, variances and covariance structure, given sufficient starting values.

The general equitation of VAR model is as follows:

$$
\Delta Y_{t}=\beta_{0}+\sum_{i=1}^{n} \beta_{1 i} \Delta Y_{t-1}+u_{t 1}
$$

whereas $\Delta Y_{t}$ is the vector of response time series variable at time $t . \Delta Y_{t}$ has $n$ elements. $\beta_{0}$ is a constant vector of offsets, with $n$ elements. $\beta_{1 i}$ are $n$-by- $n$ matrices for each $i . u_{t 1}$ is a vector od serially uncorrelated innovations, vectors of lengths $n$. The $u_{t 1}$ are multivariate normal random vectors with a covariance matrix $Q$, where $Q$ is an identity matrix, unless otherwise specified.

There is a number of studies employed VARmodel to assess the impact of the Global financial economic crisis on macroeconomic variables. Mariano et al [28] provided a theoretical aspect of VAR-approach employment in modeling financial and economic crises. Josifidis et al [29] studied the impact and macroeconomic policy responses to the financial crisis in emerging European countries and Akinci [30] on developing countries. Gimet [31] applied a Structural VAR model to assess the stress of the financial crisis in ASEAN countries. Additionally, there are very few scholar articles employed VAR model for analyzing the impact of the Global financial economic crisis on public budget and unemployment. So far Bermperoglou et al [32] studied spending cuts and their effects on output, unemployment and the deficit in the US, Canada, Japan, and the UK. In particularly, Giorgi et al [33] employed VAR model to show how to make a conditional forecast and perform impulse response functions and counterfactual analysis of the effects of fiscal policy on macroeconomic variables of USA. Also, Wang et al [34] examined the dynamic effects of government outlays on economic growth and the un- 
employment rate using vector autoregression for twenty OECD countries.

\subsection{Data and Methodology}

We use seasonally adjusted quarterly data from 2005 to 2013 to study the transmission mechanism of the Global financial crisis on the economy of the Kyrgyz Republic. The data set includes the following variables:

DLLIQUID: liquidity ratio;

DLDEPOSIT: deposits of the banking system of $\mathrm{KR}$;

DLREMIT: remittances inflow;

DLEX: exchange rate KGS to US dollar;

DLBEXP: public spending;

DLBREV: public revenue;

DLUNEMP: unemployment rate.

The data statistics is taken from National Bank of the Kyrgyz Republic dataset and the National Statistics Committee of the Kyrgyz Republic.

The transmission channels are divided into two groups: financial sector channels and real sector channels. The external crisis shock on the economy of a country transmitted via channels, for this reason, to estimate the VAR model the Granger Causality test have been analyzed firstly (Table 1.)

The test indicates that in the constructed model provides significant Granger effect between the following variables: bexp $\rightarrow$ liquid, unemp $\rightarrow$ bexp, bexp $\rightarrow$ dlunemp, dlunemp $\rightarrow$ brev, brev $\rightarrow$ unemp. The Granger Causality test results show that public spending and public revenue have a significant effect on unemployment level. Therefore, this states that expansionary fiscal policy might have concussive effect on unemployment level of a country.

Akaike and Schwartz information criteria were used to determine the specification of the model and to choose the optimal number to be included in it lagged variables that are equal to one-quarter. The optimal lag length was determined based on the resulting test values: LR-consistently modified likelihood ratio test; FPE - final or final, the prediction error; AIC - values of Akaike information criterion, SIC - values Schwarz information criterion, $\mathrm{HQ}$ - value information criterion henna-Quinn. The test results suggested same optimal three lag lengths for VAR model as seen in Table 2.

The VAR-model employed in the analysis is given below:

$$
\Delta Y_{t}=\beta_{0}+\sum_{i=1}^{n} \beta_{1 i} \Delta Y_{t-1}+\sum_{i=0}^{n} \beta_{2 i} \Delta X_{t-1}+u_{t 1} .
$$

The exact models employed in the analysis are the followings:

$$
\begin{aligned}
& \Delta \text { dlremit }=\beta_{0}+\beta_{11} \Delta \text { dlremit }_{t-1}+ \\
& +\beta_{21} \text { ddldeposit }_{t-1}+\beta_{31} \text { sdlliquid }_{t-1}+ \\
& +\beta_{41} \Delta \text { dlbexp }_{t-1}+\beta_{51} \Delta \text { dlbrev }_{t-1}+ \\
& +\beta_{61} \Delta \text { dlunemp } p_{t-1}+\beta_{71} \Delta \text { dler } r_{t-1}+u_{t 1} \text {; } \\
& \Delta \text { dldeposit }=\beta_{0}+\beta_{11} \Delta \text { dldeposit }_{t-1}+ \\
& +\beta_{21} \Delta_{\text {dlliquid }_{t-1}}+\beta_{31} \Delta \text { dlbexp }_{t-1}+ \\
& +\beta_{41} \Delta \text { dlbrev }_{t-1}+\beta_{51} \Delta \text { dlunemp }_{t-1}+ \\
& +\beta_{61} \Delta \text { dler }_{t-1}+\beta_{71} \Delta \text { dlremit }_{t-1}+u_{t 1} ; \\
& \Delta \text { dlliquid }=\beta_{0}+\beta_{11} \Delta \text { dlliquid }_{t-1}+ \\
& +\beta_{21} \Delta \text { dlbexp }_{t-1}+\beta_{31} \Delta \text { dlbrev }_{t-1}+ \\
& +\beta_{41} \Delta \text { dlunemp }_{t-1}+\beta_{51} \Delta \text { dler }{ }_{t-1}+ \\
& +\beta_{61} \Delta \text { dlremit }_{t-1}+\beta_{71} \Delta \text { dldeposit }_{t-1}+u_{t 1} \text {; } \\
& \Delta \text { dlbexp }=\beta_{0}+\beta_{11} \Delta \text { dlbexp }+ \\
& +\beta_{21} \Delta \text { dlbrev }_{t-1}+\beta_{31} \Delta \text { dlunemp }_{t-1}+ \\
& +\beta_{41} \Delta \text { dler }_{t-1}+\beta_{51} \Delta \text { dlremit }_{t-1}+ \\
& +\beta_{61} \Delta \text { dldeposit }_{t-1}+\beta_{71} \Delta \text { dlliquid }_{t-1}+u_{t 1} \text {; } \\
& \Delta \text { dlbrev }=\beta_{0}+\beta_{11} \Delta \text { dlbrev }_{t-1}+ \\
& +\beta_{21} \Delta \text { dlunemp } p_{t-1}+\beta_{31} \Delta \text { dler }_{t-1}+ \\
& +\beta_{41} \Delta \text { dlremit }_{t-1}+\beta_{51} \Delta \text { dldeposit }_{t-1}+ \\
& +\beta_{61} \Delta \text { dlliquid }_{t-1}+\beta_{71} \Delta \text { dlbexp }_{t-1}+u_{t 1} \\
& \Delta \text { dlunemp }=\beta_{0}+\beta_{11} \Delta \text { dlunemp }_{t-1}+ \\
& +\beta_{21} \Delta \text { dler }_{t-1}+\beta_{31} \Delta \text { dlremit }_{t-1}+ \\
& +\beta_{41} \Delta \text { dldeposit }_{t-1}+\beta_{51} \Delta \text { dlliquid }_{t-1}+ \\
& +\beta_{61} \Delta \text { dlbexp }_{t-1}+\beta_{71} \Delta \text { dlbrev }_{t-1}+u_{t 1} \text {; } \\
& \Delta \text { dler }=\beta_{0}+\beta_{11} \Delta \text { dler }_{t-1}+\beta_{21} \Delta \text { dlremit }_{t-1}+ \\
& +\beta_{31} \Delta \text { dldeposit }_{t-1}+\beta_{41} \Delta \text { dlliquid }_{t-1}+ \\
& +\beta_{51} \Delta \text { dlbexp }_{t-1}+\beta_{61} \Delta \text { dlbrev }_{t-1}+ \\
& +\beta_{71} \Delta \text { dlunemp } p_{t-1}+u_{t 1} ;
\end{aligned}
$$

The VAR-model is built on the criteria based on Granger Causality test and the output of VAR Lag Order Selection Criteria.

The model shows the response on a shock (change) of exogenous variables on endogenous. The VAR-model suggests that there is a significant impact of external shock on the liquidity of the banking system, exchange rate, remittances inflow, and public revenue and spending. Indeed, the model proved that countries with transition economies effected by Global financial crisis through the common channels as banking sector, remittances, international trade, exchange rate channels and their impact on the public budget and unemployment level. The relevant issue is the further transmission of the crisis on a country`s economy.

In VAR analysis, it is often difficult to interpret the coefficient estimates because the error terms 
Table 1

Pairwise Granger Causality Tests

\begin{tabular}{|l|c|c|c|}
\hline Sample: 2005Q1 2013Q4 & \multicolumn{2}{l|}{} \\
\hline Lags: 2 & Obs & F-Statistic & Probability \\
\hline Null Hypothesis: & 33 & 1.61955 & 0.2160 \\
\hline DLLIQUID does not Granger Cause DLBEXP & & 4.02216 & $\mathbf{0 . 0 2 9 1}^{*}$ \\
\hline DLBEXP does not Granger Cause DLLIQUID & 33 & 0.37448 & 0.6910 \\
\hline DLREMIT does not Granger Cause DLBEXP & & 0.20664 & 0.8145 \\
\hline DLBEXP does not Granger Cause DLREMIT & 33 & 15.2075 & $\mathbf{3 . E}^{*}$ \\
\hline DLUNEMP does not Granger Cause DLBEXP & & 16.2643 & $\mathbf{2 . E}^{*}$ \\
\hline DLBEXP does not Granger Cause DLUNEMP & 33 & 6.46307 & 0.0049 \\
\hline DLER does not Granger Cause DLBREV & & 0.73482 & 0.4886 \\
\hline DLBREV does not Granger Cause DLER & 33 & 8.81627 & $\mathbf{0 . 0 0 1 1}^{*}$ \\
\hline DLUNEMP does not Granger Cause DLBREV & & 6.53353 & $\mathbf{0 . 0 0 4 7}^{*}$ \\
\hline DLBREV does not Granger Cause DLUNEMP & &
\end{tabular}

Source: Authors` calculations.

Table 2

VAR Lag Order Selection Criteria

Cholesky ordering (from exogenous to endogenous variable): remit deposit liquid bexp brev unemp er

\begin{tabular}{|c|c|c|c|c|c|c|}
\hline \multicolumn{3}{|c|}{ VAR Lag Order Selection Criteria } & & & & \\
\hline \multicolumn{7}{|c|}{ Endogenous variables: DLREMIT DLDEPOSIT DLLIQUID DLBEXP DLBREV DLUNEMP DLER } \\
\hline \multicolumn{7}{|c|}{ Exogenous variables: $\mathrm{C}$} \\
\hline \multicolumn{7}{|c|}{ Sample: 2005Q1 2013Q4 } \\
\hline \multicolumn{7}{|c|}{ Included observations: 32} \\
\hline Lag & $\log L$ & LR & FPE & AIC & SC & HQ \\
\hline 0 & 165.7253 & NA & $1.16 \mathrm{e}-13$ & -9.920329 & $-9.599699^{*}$ & -9.814049 \\
\hline 1 & 225.1790 & 89.18056 & $6.51 \mathrm{e}-14$ & -10.57369 & -8.008648 & -9.723448 \\
\hline 2 & 293.5956 & $72.69265^{*}$ & $3.13 \mathrm{e}-14$ & -11.78722 & -6.977778 & -10.19303 \\
\hline 3 & 399.4544 & 66.16174 & $4.54 e-15^{\star}$ & $-15.34090^{*}$ & -8.287044 & $-13.00275^{*}$ \\
\hline \multicolumn{7}{|c|}{${ }^{*}$ indicates lag order selected by the criterion } \\
\hline \multicolumn{7}{|c|}{ LR: sequential modified LR test statistic (each test at $5 \%$ level) } \\
\hline \multicolumn{7}{|c|}{ FPE: Final prediction error } \\
\hline \multicolumn{7}{|c|}{ AIC: Akaike in formation criterion } \\
\hline \multicolumn{7}{|c|}{ SC: Schwarz information criterion } \\
\hline HQ: Hann & informati & erion & & & & \\
\hline
\end{tabular}

Source: Authors`calculations.

tend to be contemporaneously correlated and the estimated coefficients on successive lags often switch in signs [34]. For this reason, we use the impulse response functions (IRFs) to examine the dynamic effects of a one-time shock and also investigate the causal relationship between all variables, as well as public budget and the unemployment rate using pair-wise Granger causality tests.

\section{Results and interpretations}

\subsection{Impulse response function analysis}

The empirical research results showed that the following transmission channels of the Global crisis effect on fiscal parameters such as: remittances channel, exchange rate channel, and banking channel.
Remittances channel has the inverse relationship with public revenue during first six months and with budget spending three months later. The decline in remittances inflow to the republic initially leads to decline in budget spending, afterwards within the lag of three months it increases. This may be explained as a rise of the unemployment level, as the result of remittances inflow reduction into the country. Nevertheless, there is an inverse relation between remittances inflow and public revenue. Therefore, the fact of consumption increases within 6 months because of tax income increase.

As a result, remittances channel effect on fiscal indicators in terms of public revenue and spending (Fig. 4). 
Response to Cholesky One S. D. Innovations +/-2S.E.

Response of DLBREV to DLREMIT

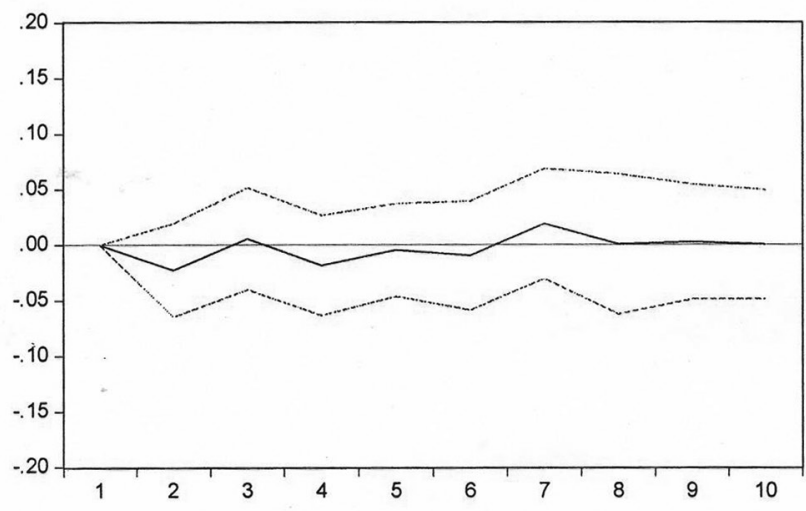

Response of DLUNEMP to DLREMIT

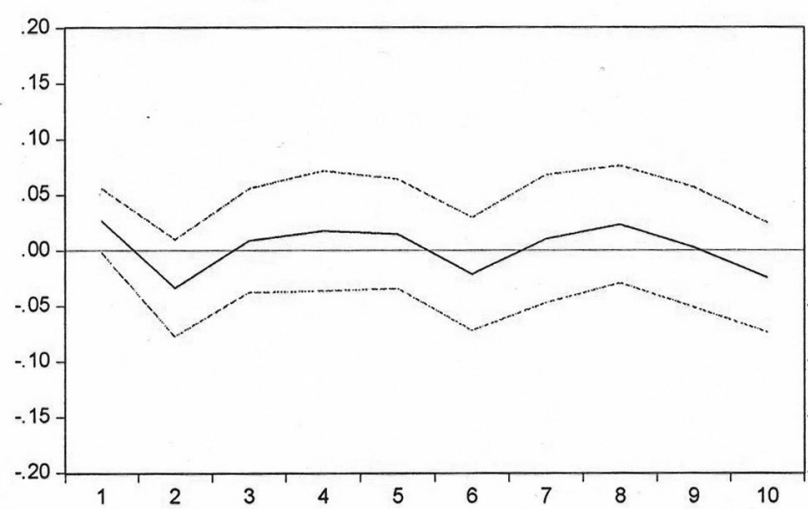

Fig. 4. Impulse Response of Public budget and unemployment to remittances

Changes in public spending as a result of an external shock is due to the change in remittances by $3,93-7 \%$ and public revenues - by $0,14-7 \%$, while the unemployment rate - at 9,29-17\%. The remittances channel with its impact of $4.74 \%$ on GDP is one of the most relevant channels of Global crisis transmission should be considered by the government of the republic in order to soften the external shocks on the economy.

Banking channel (liquidity) shows the adverse relationship with public revenue. The decrease of liquidity level of the banking system in the Kyrgyz Republic (this process can be seen dramatically in three-six months) leads to increase of public revenue and level of unemployment rate.

Conclusive shock results are received between public budget variables and deposits of the banking system. The decline of deposit volume leads to increase of public spending only in six months, whereas the impact on public revenue is insignificant, but has a conclusive tendency (Fig. 5).

Exchange rate channel adversely effects on public revenue. The depreciation of the national currency leads to increase of the public revenue, whereas unemployment level increases in three months (Fig. 6).

\subsection{Variance Decomposition Analysis}

The variance decomposition demonstrates that public spending shock is account for 3.93-8.89\% in remittances inflow, for $4-7.76 \%$ in deposits of commercial banks, and for $0.69 \%$ in liquidity level of the banking system, while own shock account for 87-59\% (see table 3). On the other hand, public revenue shock is account for $38 \%$ in liquidity level of the banking system, for $0.14-7 \%$ in remittances inflow, for 9-29\% in exchange rate, while own shock account for 52-14 \% (see table 4).

The conducted empirical analysis demonstrates that public budget (its component parts as revenue and spending) is also effected by Global financial crisis through the transmission channels, in particular, remittances inflow channel, exchange rate, and banking (liquidity) channels, which afterwards affect the level of unemployment (confirmed Hypothesis 1).

\subsection{Global financial crisis impact on Unemployment}

The VAR-model on unemployment suggests that there is significant adverse effect on public spending for the first six months.

The Variance Decomposition demonstrates that unemployment shock is account for $9.29 \%$ 
Response to Cholesky One S.D. Innovations +/-2S.E.

Response of DLBREV to DLLIQUID

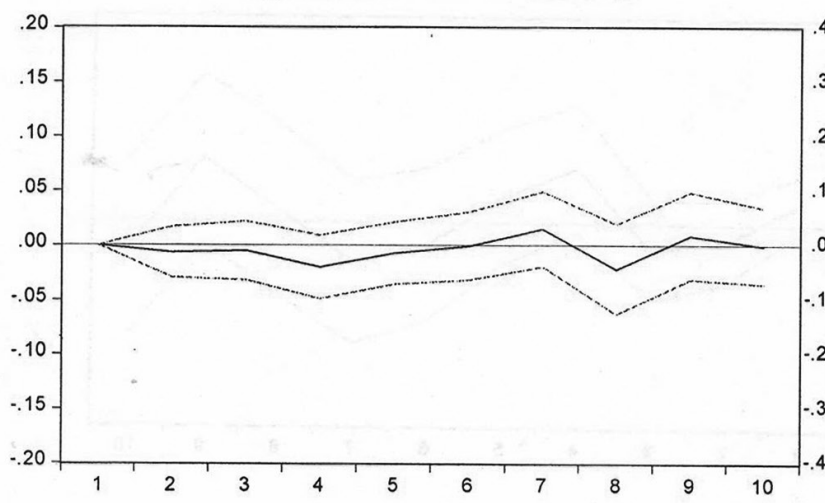

Response of DLBEXP to DLDEPOSIT

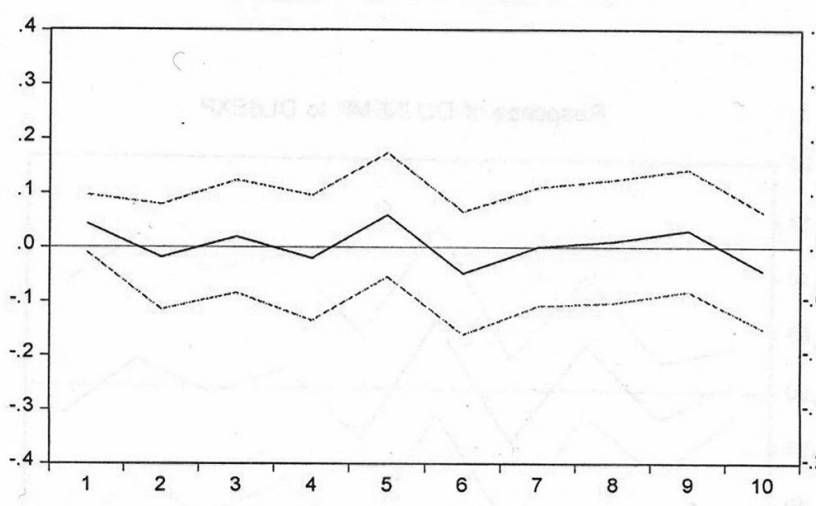

Response of DLBEXP to DLLIQUID

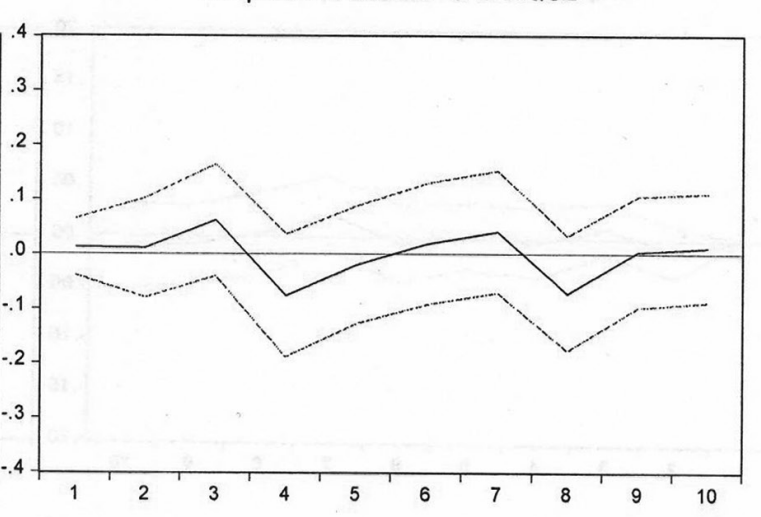

Response of DLBREV to DLDEPOSIT

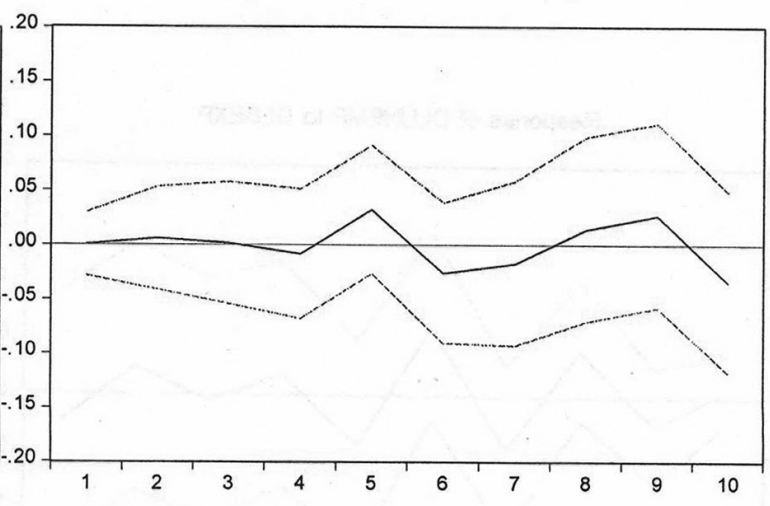

Response of DLUNEMP to DLLIQUID

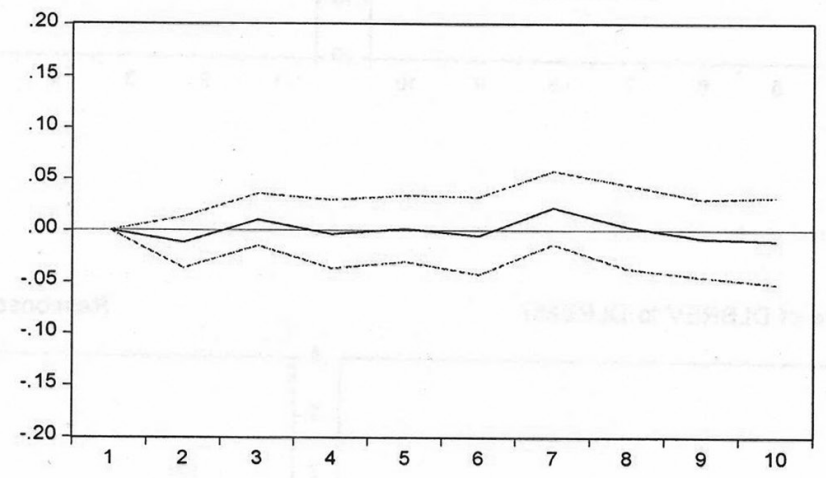

Fig. 5. Impulse Response of public budget to deposit and liquidity

Response to Cholesky One S.D. Innovations +/- 2S.E.

\section{Response of DLBREV to DLER}

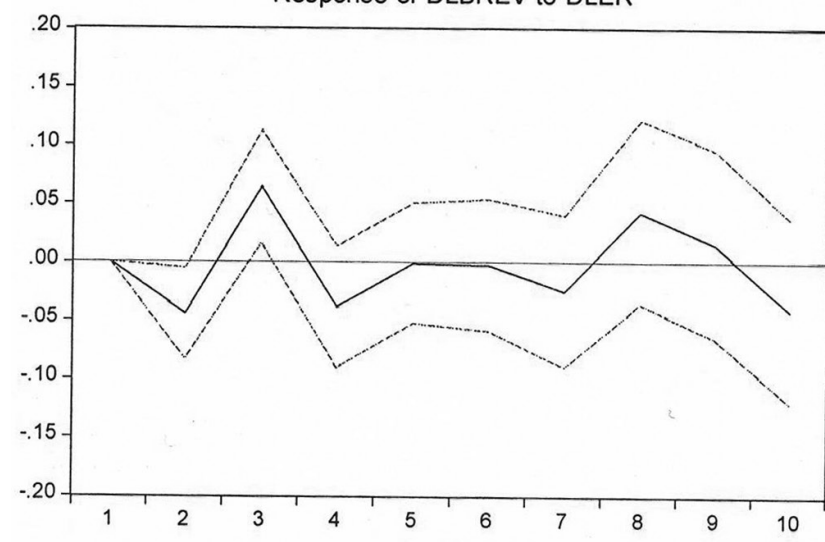

Response of DLUNEMP to DLER

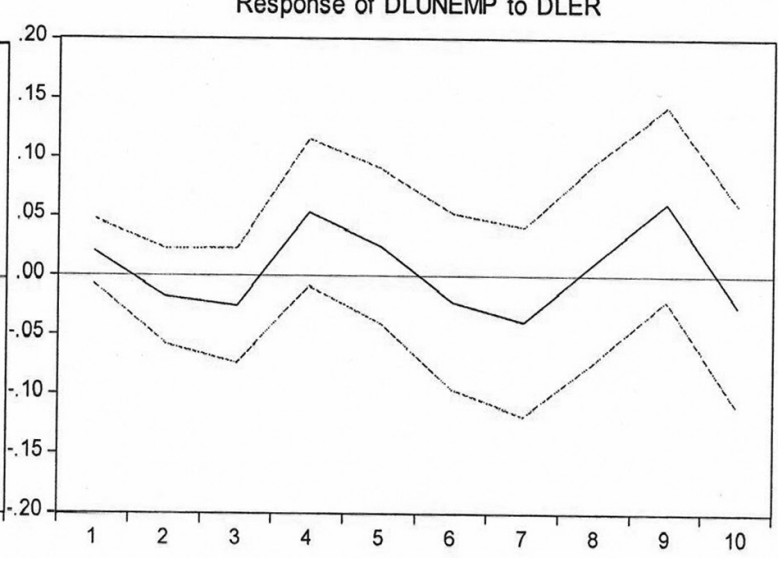

Fig. 6. Impulse Response of public budget and unemployment to exchange rate 
Variance Decomposition of public spending, \%

\begin{tabular}{|c|c|c|c|c|c|c|c|c|}
\hline Period & S.E. & DLREMIT & DLDEPOSIT & DLLIQUID & DLBEXP & DLBREV & DLUNEMP & DLER \\
\hline 1 & 0.156690 & 3.939583 & 7.667030 & 0.696583 & 87.69680 & 0.000000 & 0.000000 & 0.000000 \\
\hline 2 & 0.232834 & 6.061334 & 4.093006 & 0.558022 & 84.90383 & 3.217206 & 1.149157 & 0.017445 \\
\hline 3 & 0.254199 & 8.898714 & 4.042861 & 6.507114 & 74.39281 & 2.702582 & 1.062792 & 2.393132 \\
\hline 4 & 0.274199 & 7.799099 & 4.017294 & 13.30280 & 64.02953 & 2.333873 & 2.924506 & 5.592895 \\
\hline 5 & 0.298572 & 6.589223 & 7.407042 & 11.65519 & 62.44488 & 3.896338 & 2.877041 & 5.130288 \\
\hline 6 & 0.331230 & 7.252775 & 8.130032 & 9.795993 & 62.87218 & 4.699891 & 2.589312 & 4.659821 \\
\hline 7 & 0.346547 & 8.260839 & 7.427691 & 10.37729 & 62.52553 & 4.572854 & 2.522944 & 4.312852 \\
\hline 8 & 0.358953 & 7.805283 & 7.015019 & 13.67408 & 59.57468 & 4.262658 & 3.632236 & 4.036040 \\
\hline 9 & 0.367464 & 7.456453 & 7.409482 & 13.06108 & 59.72770 & 4.080548 & 3.507320 & 4.757416 \\
\hline 10 & 0.382683 & 7.264332 & 8.114492 & 12.14115 & 58.70641 & 3.762855 & 3.529388 & 6.481372 \\
\hline
\end{tabular}

Table 4

Variance Decomposition of public revenue, $\%$

\begin{tabular}{|c|c|c|c|c|c|c|c|c|}
\hline Period & S.E. & DLREMIT & DLDEPOSIT & DLLIQUID & DLBEXP & DLBREV & DLUNEMP & DLER \\
\hline 1 & 0.082571 & 0.143962 & 0.010780 & 38.30506 & 8.731551 & 52.80864 & 0.000000 & 0.000000 \\
\hline 2 & 0.110379 & 7.334472 & 0.316224 & 21.94329 & 16.47246 & 32.23059 & 11.77561 & 9.927346 \\
\hline 3 & 0.129870 & 5.469227 & 0.247192 & 15.85450 & 11.90301 & 27.79423 & 9.662102 & 29.06974 \\
\hline 4 & 0.142966 & 5.671183 & 0.544968 & 17.48712 & 11.66796 & 22.94374 & 7.978026 & 33.70701 \\
\hline 5 & 0.155931 & 4.786508 & 4.817994 & 20.66554 & 11.55750 & 22.96555 & 6.803334 & 28.40357 \\
\hline 6 & 0.181731 & 5.619150 & 5.573818 & 18.06767 & 24.75897 & 19.01096 & 6.025923 & 20.94350 \\
\hline 7 & 0.217668 & 7.191572 & 4.498609 & 13.15043 & 39.94403 & 15.43322 & 4.378582 & 15.40355 \\
\hline 8 & 0.236292 & 6.298729 & 4.186171 & 14.94866 & 40.18471 & 14.43405 & 5.314751 & 14.63293 \\
\hline 9 & 0.241745 & 6.180459 & 5.258163 & 15.13506 & 39.62916 & 13.80894 & 5.262790 & 14.72543 \\
\hline 10 & 0.251171 & 5.853887 & 6.738559 & 14.06469 & 38.99298 & 12.80110 & 4.876783 & 16.67200 \\
\hline
\end{tabular}

Cholesky Ordering: DLREMIT DLDEPOSIT DLLIQUID DLBEXP DLBREV DLUNEMP DLER.

Source: Authors ' calculations.

in remittances inflow, for $34 \%$ in liquidity level of the banking system, for $0.53-18 \%$ in public spending (see table 5).

The Granger test indicates that unemployment level has a significant Granger effect on public spending; on the other hand, there is inverse relationship between public spending and unemployment level. Therefore, public spending increase causes the decline in unemployment level within IS-LM model.
In order to demonstrate the public spending effect on unemployment level, we conducted Least squares method to have empirically proved output (see table 6 and fig. 7). The model employed in the analysis is the following:

$$
\begin{gathered}
\text { DLBEXP }=0.0636484250303+ \\
+0.632070983239 \times \text { DLUNEMP }
\end{gathered}
$$

The model with a sample of quarterly adjusted data from 2nd quarter of 2005 till 4 th quar-

Response to Cholesky One S.D. Innovations +/-2S.E.

Response of DLUNEMP to DLBEXP

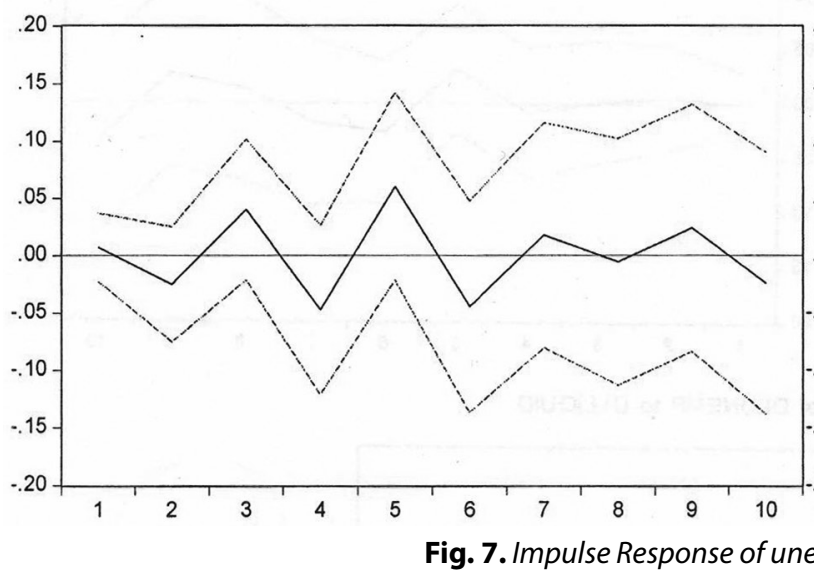

Response of DLUNEMP to DLBEXP

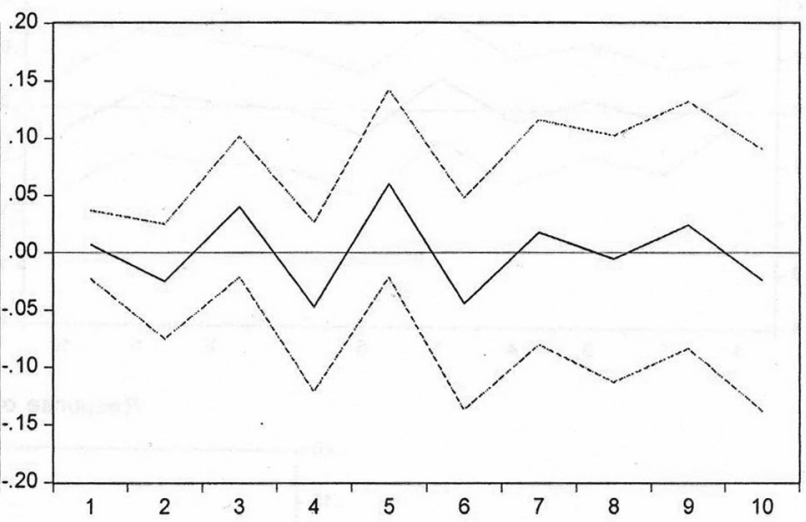

Fig. 7. Impulse Response of unemployment to public spending 
Table 5

Variance Decomposition of unemployment, \%

\begin{tabular}{|c|c|c|c|c|c|c|c|}
\hline S.E. & DLREMIT & DLDEPOSIT & DLLIQUID & DLBEXP & DLBREV & DLUNEMP & DLER \\
\hline 0.088494 & 9.299901 & 1.391031 & 34.89880 & 0.532224 & 0.956629 & 52.92142 & 0.000000 \\
\hline 0.109760 & 17.99040 & 6.195292 & 23.33989 & 6.548586 & 0.684581 & 44.58927 & 0.651979 \\
\hline 0.146306 & 11.54446 & 13.70606 & 18.96462 & 16.91943 & 4.638531 & 33.40501 & 0.821889 \\
\hline 0.167839 & 9.062058 & 10.43136 & 14.50467 & 18.32401 & 11.85784 & 27.60032 & 8.219743 \\
\hline 0.193962 & 8.499054 & 17.27497 & 16.68354 & 16.21085 & 9.764837 & 24.95316 & 6.613580 \\
\hline 0.205175 & 9.864208 & 15.44711 & 16.06465 & 20.03725 & 8.903497 & 22.32983 & 7.353449 \\
\hline 0.230679 & 8.250092 & 14.61990 & 22.34624 & 18.03748 & 7.623717 & 22.68494 & 6.437639 \\
\hline 0.233927 & 8.962038 & 15.11990 & 21.92010 & 17.54805 & 7.806129 & 22.16832 & 6.475457 \\
\hline 0.250377 & 7.915232 & 17.52974 & 20.58953 & 15.47418 & 7.442984 & 21.39429 & 9.654041 \\
\hline 0.259007 & 8.743793 & 16.64494 & 20.91091 & 16.00797 & 7.072749 & 20.12150 & 10.49814 \\
\hline
\end{tabular}

Cholesky Ordering: DLREMIT DLDEPOSIT DLLIQUID DLBEXP DLBREV DLUNEMP DLER.

Source: Authors ' calculations.

Table 6

Regression model

\begin{tabular}{|c|c|c|c|c|}
\hline \multicolumn{5}{|c|}{ Dependent Variable: DLBEXP } \\
\hline \multicolumn{5}{|c|}{ Method: Least Squares } \\
\hline \multicolumn{5}{|c|}{ Sample (adjusted): 2005Q2 2013Q4 } \\
\hline \multicolumn{5}{|c|}{ Included observations: 35 after adjustments } \\
\hline Variable & Coefficient & Std. Error & t-Statistic & Prob. \\
\hline $\mathrm{C}$ & 0.063648 & 0.056409 & 1.128332 & 0.2673 \\
\hline DLUNEMP & 0.632071 & 0.254434 & 2.484228 & 0.0182 \\
\hline R-squared & 0.157548 & \multicolumn{2}{|l|}{ Mean dependent var } & 0.063046 \\
\hline Adjusted R-squared & 0.132020 & \multicolumn{2}{|l|}{ S.D. dependent var } & 0.358200 \\
\hline S.E. of regression & 0.333719 & \multicolumn{2}{|l|}{ Akaike info criterion } & 0.698409 \\
\hline Sum squared resid & 3.675152 & \multicolumn{2}{|l|}{ Schwarz criterion } & 0.787286 \\
\hline Log likelihood & -10.22216 & \multicolumn{2}{|l|}{ Hannan-Quinn criter. } & 0.729090 \\
\hline F-statistic & 6.171388 & \multicolumn{2}{|l|}{ Durbin-Watson stat } & 2.982118 \\
\hline Prob(F-statistic) & 0.018233 & & & \\
\hline
\end{tabular}

Source: Authors' calculations.

ter of 2013 suggests that increase of unemployment level by $1 \%$ requires the increase of public spending by $0.63 \%$, as a macroeconomic stabilization policy within the Mundell-Fleming (IS-LM) framework (confirmed Hypothesis 2).

\section{Conclusions and Policy implications}

The Global financial crisis hit the economy of the Kyrgyz Republic by the third wave of its transmission in the early of 2009 as long as other developing countries and many countries with transition economies. This study examined the Global financial crisis impact on the public budget and unemployment within IS-LM model for small open economies with floating exchange rate. It should be underlined that the study results identified the relation in terms of trends, and are applicable to many transition economies, but the specific empirical relationships and time lags refer specifically to the economy of the Kyrgyz Republic.

The first strand of the study results indicates that the effects of an external shock disseminated through the channels of transmission and has impact on fiscal indicators. Reduced remittances inflow leads to adverse consequences on the public budget (increase in both public spending and revenue) and consecutively to an increase in unemployment level. On the contrary, the second strand of the results investigates the reduction of liquidity level of the banking system that has significant inverse effect on the public budget in 3-6 months after the crisis shock, while the change in the liquidity instantly reflects the level of unemployment. The third stand of the results demonstrates that the change in volume of deposits, as a reverse relationship, affects public spending in 6 months, while the impact on public revenues are not expressed clearly and particularly insignificant within the first nine months, but has a conclusive tendency. The final strand of results indicates that the fall of the exchange rate (devaluation of the national currency) leads to increase in public revenues, and in turn the rise in the unemployment rate within the lag of three months. 
By concluding the study results, it must be underlined that the fall in remittances inflow, liquidity level of the banking system, depreciation of the national currency lead to an increase in public revenue. Therefore, IS-LM model for small open economy with floating exchange rate suggests conduction of expansionary fiscal policy. In this sense, the increase in public spending (government pur- chases) during the crisis period, with the aim of unemployment reduction, might be considered as a crucial policy. The result of the study indicates that increase of unemployment level by $1 \%$ requires the increase of public spending by $0.63 \%$. Nevertheless, the government should take into account the adverse effects associated with the impact of the crisis on the public budget as a whole.

\section{References}

1. Wang, J.-Ch. (2010). The strategies adopted by Taiwan in response to the Global financial crisis, and Taiwan 's role in Asia-Pacific economic integration. Japan and the World Economy, 22, 254-263.

2. Rose, A. K. \& Spiegel, M. M. (2012). Cross-country causes and consequences of the 2008 crisis: Early warning. Japan and the World Economy, 24, 1-16.

3. Gurtner, B. (2010). The Financial and Economic crisis and Developing countries. Dossier/Africa: 50 years of independence. Review/ Major development policy trends, 183-213.

4. Javanovic, B. \& Petreski, M. (2014). Monetary policy, exchange rates and labor unions in SEE and the CIS during the financial crisis. Economic Systems, 38(3), 309-332.

5. Aizenman, J. \& Jinjarak, Y. (2011). The role of fiscal policy in response to the financial crisis. World Economic Situation and Prospects Background, 1-36.

6. Ghosh, A. R., Chamon, M., Crowe, C., Kim, J. I. \& Ostry, J. D., (2009). Coping with the crisis: Policy options for Emerging Market Economies. IMF Staff Position Note, 8. Retrieved from: http://citeseerx.ist.psu.edu/viewdoc/download?doi=10.1.1.218.7978\&rep=rep1\&type $=$ pdf (date of access: 20.11 .15$)$.

7. Freedman, C., Kumhof, M., Laxton, D. \& Lee, J. (2009). The Case for Global Fiscal Stimulus. IMF Staff Position Note, 3. Retrieved from: https://www.imf.org/external/pubs/ft/spn/2009/spn0903.pdf (date of access: 7.12.2015).

8. Kandil, M., \& Morsy, H. (2010). Fiscal Stimulus and Credibility in Emerging countries. IMF country Report, 123. Retrieved from: https://www.imf.org/external/pubs/ft/wp/2010/wp10123.pdf (date of access: 20.11.15).

9. Kazi, M. (2014) Investigating the Transmission Channels of the Global Financial Crisis to Tanzania. Modern Economy, 5, 324-332.

10. Kumar, R., \& Soumya, A. (2010). Fiscal Policy Issues for India after the Global Financial Crisis (2008-2010). ADBI Working Paper 249. Tokyo: Asian Development Bank Institute. Retrieved from: https://www.adb.org/sites/default/files/publication/156104/adbi-p249.pdf (date of access: 25.12.2015).

11. Rendahl, P. (2012). Fiscal Policy in an Unemployment Crisis. Cambridge Working paper series, 1405. Retrieved from: http://www.econ.cam.ac.uk/research/repec/cam/pdf/cwpe1405.pdf (date of access: 7.12.2015).

12. Bradforddelong, J. \& Summers, L. H. (2012). Fiscal Policy in a Depressed Economy. Brookings Papers on Economic Activity, 233-297.

13. Hong, K. (2010). Fiscal Policy Issues in Korea after the Current Crisis. ADBI Working Paper, 225. Retrieved from: https://www.adb.org/sites/default/files/publication/156080/adbi-p225.pdf (date of access: 20.11.2015).

14. Fetai, B. (2013). The effectiveness of fiscal and monetary policy during the financial crisis. Journal of Economics and Business, 16(2), 3-66.

15. Golmohammadpoor, A. K. \& Mansoori, M. (2011). 2008 Economic Crisis Analysis. MPRA Paper, 33664. Retrieved from: https://mpra.ub.uni-muenchen.de/33664/1/MPRA_paper_33664.pdf (date of access: 20.11.2015).

16. Hollmayr, J. \& Matthes, C. (2013). Learning about fiscal policy and the effects of policy uncertainty. Discussion Paper Deutsche Bundes bank, 51. Retrieved from: https://www.bundesbank.de/Redaktion/EN/Downloads/Publications/ Discussion_Paper_1/2013/2013_11_25_dkp_51.pdf?_blob=publicationFile (date of access: 20.11.2015).

17. Lupu, I. (2012). From the Financial Crisis to the Real Economy: the Main Channels of Transmission through a Theoretical Perspective. EuroEconomica. Knowlegde in Finance and Accounting, 2(31), 45-50.

18. Stiglitz, J. E. (2011). Global Crisis the way forward: the Stiglitz Commission Report. New Delhi: Orient BlackSwan, 204.

19. Reddy, Y. V. (2011). Global Crisis Recession and Uneven Recovery. New Delhi: Orient BlackSwan, 421.

20. Gomes de Silva, Cleomar and Vilela Vieira, Flavio (2014, December). Monetary and fiscal policy in the world economy: coordination before and after the financial crisis. Macroeconomia Aplicada 36 Encontro Brasileiro de Econometria, 9(12). Retrieved from: https://editorialexpress.com/cgi-bin/conference/download.cgi?db_name=SBE36\&paper_id=18 (date of access: 7.12.2015).

21. Andersen, T. M. (2009). Fiscal policy and the global financial crisis. Economics Working Paper, 7. Retrieved from: http://citeseerx.ist.psu.edu/viewdoc/download?doi=10.1.1.630.8381\&rep=rep1\&type=pdf (date of access: 7.12.2015).

22. Holden, S., Sparrman, V. (2011). Do government purchases affect unemployment? CES-Ifo Working Paper, 3482. Retrived fromhttp://www.cesifo-group.de/ifoHome/publications/working-papers/CESifoWP/CESifoWPdetails?wp_ num $=3482 \&$ CESifoWP.search $=+($ date of access: 7.12 .2015$)$. 
23. Coenen, G., Erceg, C. J., Freedman, C., Furceri, D., Kumhof, M., Lalonde, R., Laxton, D., Lind'e, J., Mourougane, A., Muir, D., Mursula, S., Resende, C., de, Roberts, J., Roeger, W., Snudden, S., Trabandt, M., \& Veld, J. (2012). Effects of fiscal stimulus in structural models. American Economic Journal, Macroeconomics, 4(1), 22-68.

24. Monacelli, T., Perotti, R. \& Trigari A. (2010). Unemployment Fiscal Multipliers. Journal of Monetary Economics, 57, 531-553.

25. Auerbach, A. J. \& Gorodnichenko, Y. Y. (2012). Fiscal multipliers in recession and expansion in Fiscal Policy after the Financial Crisis. The University of Chicago Press, 99(2), 543-549.

26. Ramey, V. A. (2012). Government Spending and Private Activity. Fiscal Policy after the Financial Crisis. In: A. Alesina and F. Giavazzi (Eds). Chicago: University of Chicago Press, 704 (19-55).

27. Pfaff, B. (2008). VAR, SVAR and SVEC Models: Implementation Within R Package vars. Journal of Statistical Software, 27(4). Retrieved from: https://cran.r-project.org/web/packages/vars/vignettes/vars.pdf (date of access: 29.07.2015).

28. Mariano, R. S., Gultekin, B. N., Ozmucur, S. \& Shabbir, T. (2000). Models of Financial and Economic Crises. Topics in Middle Eastern and North African Economies, 2. Retrieved from: http://www.luc.edu/orgs/meea/volume2/PDFS/ Models\%20of\%20Economic\%20and\%20Financial.pdf (date of access: 29.07.2015).

29. Josifidis, K., Allegret, J. P., Gimet, C. \& Pucar, E. B. (2014). Macroeconomic policy responses to financial crises in emerging European economies. Economic Modelling, 36, 577-591.

30. Akinci, O. (2013). Global Financial Conditions, Country Spreads and Macroeconomic Fluctuations in Emerging Countries. International Finance Discussion Papers, 1085. Retrieved from: https://www.federalreserve.gov/pubs/ ifdp/2013/1085/ifdp1085.pdf (date of access: 29.07.2015).

31. Gimet, G. (2009). The impact of financial crises in Asean countries: A Structural Var model, University of Lyon Group for Economic Analysis and Theory (GATE), 2, 1-16.

32. Bermperoglou, D., Pappa, E. \& Vella, E. (2013). Spending cuts and their effects on output, unemployment and the deficit”. European University Institute mimeo. Retrieved from: http://apps.eui.eu/Personal/Pappa/Papers/DimEugEvi_17DEC13. pdf (date of access: 29.07.2015).

33. Giorgi, G. \& Gambetti, L. (2012). The Effects of Government Spending on the Distribution of Consumption. Barcelona GSE Working Paper Series, 645. Retrieved from: http://pareto.uab.es/wp/2012/90512.pdf (date of access: 29.07.2015).

34. Wang, S. \& Abrams, B. A. (2011). Government Outlays, Economic Growth and Unemployment: A VAR Model. University of Delaware Working paper series, 13. Retrieved from: http://lerner.udel.edu/sites/default/files/ECON/PDFs/ RePEc/dlw/WorkingPapers/2011/UDWP2011-13.pdf (date of access: 29.07.2015).

\section{Authors}

Nargiza Bakytovna Alymkulova - PhD in Economics, Finance and Banking Department, International Ataturk Alatoo University (1/8, Ankara St., Kyrgyzstan, 720048, Bishkek; email: nargizalymkulova@gmail.com).

Nurlan Uzgenovich Atabaev - PhD in Economics, Dean of Economics and Administrative Sciences Faculty, International Ataturk Alatoo University (1/8, Ankara St., Kyrgyzstan, 720048, Bishkek; e-mail: nurlan.atabaev@iaau.edu.kg).

Junus Mashrapovich Ganiev - Associate Professor, PhD in Economics, Deputy Head of Economics Department, Kyrgyzstan-Turkey Manas University (56, Mira Ave., Bishkek, 720044, Kyrgyzstan; e-mail: econom03@gmail.com). 